The 63rd special issue "New Developments of Electrochemical Capacitors"

\title{
Structural Analysis of Furfural Resin-based Active Carbon to Control an Electric Double-layer Capacitor Kanade HOKARI, ${ }^{\mathrm{a}, *}$ Shinichiro SUZUKI, ${ }^{\text {a }}$ Naoki OKAMOTO, ${ }^{\text {a }}$ Takeyasu SAITO, ${ }^{\mathrm{a}}$ Isamu IDE, ${ }^{\mathrm{b}}$ Masanobu NISHIKAWA, ${ }^{\mathrm{b}}$ and Yoshikazu ONISHI ${ }^{\mathrm{b}}$
}

a Dept. of Chemical Engineering, Osaka Prefecture University, 1-1 Gakuen-cho, Naka-ku, Sakai, Osaka 599-8531, Japan

b LIGNYTE. CO., LTD., 2-5 Chikkoshinmachi, Nishi-ku, Sakai, Osaka 592-8331, Japan

*Corresponding author: khokari@chemeng.osakafu-u.ac.jp

\begin{abstract}
Active carbon was prepared by treating carburized furfural resin particles $(1 \mu \mathrm{m}$ in diameter) with potassium hydroxide solution for $0-0.5 \mathrm{~h}$ at $700-800^{\circ} \mathrm{C}$ in flowing nitrogen gas. The pore structure of the active carbon was then evaluated by nitrogen adsorption experiments. The active carbon particles $\left(1 \mu \mathrm{m}\right.$ in diameter) prepared at $750^{\circ} \mathrm{C}-0 \mathrm{~h}$ or $800^{\circ} \mathrm{C}-0 \mathrm{~h}$ had ca. 2.5 -fold greater mesopore volume and 1.9 -fold greater mesopore ratio than those prepared at $700^{\circ} \mathrm{C}-0.5 \mathrm{~h}$. The surface chemical structure was evaluated by $\mathrm{X}$-ray photoelectron spectroscopy, while the fraction of organic functional groups in the pores was evaluated by Boehm titration. The carboxyl group fraction in the pores increased in the following order: $750^{\circ} \mathrm{C}-0 \mathrm{~h}(18.1 \%)<800^{\circ} \mathrm{C}-0 \mathrm{~h}(23.0 \%)<700^{\circ} \mathrm{C}-0.5 \mathrm{~h}(31.4 \%)$. The relationship between the pore size distribution, surface functional groups in the pores, and electric double-layer capacitor capacity was investigated for the specific surface area of $1200 \pm 100 \mathrm{~m}^{2} / \mathrm{g}$. The specific capacity increased in the following order: $700^{\circ} \mathrm{C}-0.5 \mathrm{~h}(66 \mathrm{~F} / \mathrm{g})<800^{\circ} \mathrm{C}-0 \mathrm{~h}(111 \mathrm{~F} / \mathrm{g})<750^{\circ} \mathrm{C}$ $0 \mathrm{~h}(148 \mathrm{~F} / \mathrm{g})$. This indicated that the amount of surface functional groups played a crucial role in the $6 \mathrm{M} \mathrm{KOH}$ electrolyte.
\end{abstract}

(C) The Author(s) 2020. Published by ECSJ. This is an open access article distributed under the terms of the Creative Commons Attribution 4.0 License (CC BY, http://creativecommons.org/licenses/by/4.0/), which permits unrestricted reuse of the work in any medium provided the original work is properly cited. [DOI: 10.5796/electrochemistry.20-63004]. Uploading "PDF file created by publishers" to institutional repositories or public websites is not permitted by the copyright license agreement.

\section{Keywords : Active Carbon, EDLC, Furfural Resin, Surface Chemical Structure}

\section{Introduction}

Increasing energy consumption and the global environmental crisis has led to an urgent need for sustainable energy sources and novel technologies for energy conversion and storage. ${ }^{1,2}$ Lithiumion batteries have become the mainstay of energy storage devices; lithium-sulfur batteries for mobile phones and sodium-ion batteries for stationary types are under consideration as next-generation batteries. $^{3-5}$ However, sluggish intercalation battery kinetics warrants a device that can deliver high power. The electric double-layer capacitor (EDLC) is of increasing interest as a potential alternative in applications where batteries fail to deliver high power. ${ }^{6,7}$ An EDLC can store energy via an electric double-layer at the interface between the electrode and electrolyte. ${ }^{8-10}$ This novel energy-storage device has potential widespread applications in hybrid electric vehicles, portable electronics, high-power electronic devices, and uninterruptable power supplies. ${ }^{11}$ Although its high capacity, high durability, and rapid charge-discharge capability are attractive, its low energy density is a major limitation. ${ }^{12-16}$ The specific surface area, pore size distribution, and surface functional groups are the dominant factors that control enhanced energy density (e.g., high specific surface area leads to high specific capacity). The results of some studies have suggested that pore sizes of either 0.4 or $0.7 \mathrm{~nm}$ would be suitable for aqueous electrolytes; however, some micropores (smaller than $2 \mathrm{~nm}$ ) may be inaccessible to electrolyte ions due to the narrow pore gate effect at the pore entrance, ${ }^{16,17}$ thereby resulting in specific capacity reduction. Xing et al. ${ }^{18}$ reported that the specific capacity of active carbon with a surface area of $2615 \mathrm{~m}^{2} / \mathrm{g}$ reached $355 \mathrm{~F} / \mathrm{g}$, which is much higher than the $332 \mathrm{~F} / \mathrm{g}$ reported for $3036 \mathrm{~m}^{2} / \mathrm{g}$ active carbon. Therefore, the pore size distribution of active carbon is a critical factor that determines electrochemical performance. ${ }^{16,19}$ The pore size distribution is determined by the proportions of micropores, mesopores (2-50 $\mathrm{nm}$ ), and macropores (larger than $50 \mathrm{~nm}$ ). Micropores play an essential role in the adsorption of electrolyte ions to achieve high capacity, whereas mesopores are necessary for the diffusion of electrolyte ions into active carbon, which improves micropore accessibility. ${ }^{20-22}$ Furthermore, mesopores serve as channels for ion diffusion and facilitate rapid electrolyte ion transport, thereby achieving a high rate of electrochemical performance. ${ }^{23}$ Accordingly, appropriate amounts of macropores and mesopores are desirable in active carbon to improve the energy densities of an EDLC. ${ }^{24,25}$ Surface functional groups affect the wettability of the active carbon electrode and pseudo-capacity due to redox reactions. ${ }^{26-29}$ Notably, the amounts and types of oxygen functional groups are the main determinants of surface chemical properties because these groups can significantly affect the polarity (hydrophobicity or hydrophilicity), surface charge, and active sites of active carbons. ${ }^{30-33}$ Although the conditions needed to achieve high capacity for each factor are known, the relationships between capacity and multiple factors (i.e., specific surface area, pore size distribution, and surface functional groups) are not clear. Therefore, in this study, the specific surface area was fixed at $1200 \pm 100 \mathrm{~m}^{2} / \mathrm{g}$ to eliminate the influence of specific surface area on specific capacity. The influences of pore size distribution and surface functional groups on specific capacity were then evaluated.

\section{Experimental}

Furfural resin-based particles $(1 \mu \mathrm{m}$ in diameter) were carburized in a nitrogen atmosphere for $3 \mathrm{~h}$ at a temperature ramping rate of $1{ }^{\circ} \mathrm{C} /$ min to $400^{\circ} \mathrm{C} .{ }^{34}$ The carbonized particles were mixed with $\mathrm{KOH}$ at a $\mathrm{KOH}$ :carbonized particles ratio of $4: 1$; the mixture was then activated at $700-800^{\circ} \mathrm{C}$ for the prescribed holding time, 
ranging from 0 to $0.5 \mathrm{~h}$, under flowing nitrogen gas at a temperature ramping rate of $10^{\circ} \mathrm{C} / \mathrm{min}^{34}$ After heat treatment had been performed, the active carbon was cooled to room temperature, washed with $1 \mathrm{M} \mathrm{HCl}$, rinsed with distilled water until neutral, and dried in an oven at $150^{\circ} \mathrm{C}$ for $24 \mathrm{~h} .{ }^{34}$ The Brunauer-Emmett-Teller (BET) specific surface area and total pore volume of active carbon was determined from nitrogen adsorption isotherms at $-196^{\circ} \mathrm{C}$, using a BELSORP-max automatic adsorption instrument. Micropore volume was obtained by the MP method, and mesopore volume and pore size distribution were obtained by the Barrett, Joyner, and Halenda method. Surface chemical structure was evaluated by X-ray photoelectron spectroscopy using Al K $\alpha$ X-ray radiation. Surface functional groups were evaluated by the Boehm method. ${ }^{35} \mathrm{~A}$ mixture of active carbon $(0.3 \mathrm{~g})$ and $25 \mathrm{~mL}$ of each of $0.05 \mathrm{M}$ $\mathrm{NaHCO}_{3}, 0.025 \mathrm{M} \mathrm{Na}_{2} \mathrm{CO}_{3}, 0.05 \mathrm{M} \mathrm{NaOH}$, and $0.05 \mathrm{M} \mathrm{HCl}$ was shaken for 2 days. The filtrate was titrated with $0.05 \mathrm{M} \mathrm{HCl}$ or $0.05 \mathrm{M} \mathrm{NaOH}$. The total acid amount was calculated from the amount reacted with $\mathrm{NaOH}$, the $-\mathrm{COOH}$ group/lactone group amount was calculated from the amount reacted with $\mathrm{Na}_{2} \mathrm{CO}_{3}$, the $-\mathrm{COOH}$ group amount was calculated from the amount reacted with $\mathrm{NaHCO}_{3}$, and the total base amount was calculated from the amount reacted with $\mathrm{HCl}$. The lactone group amount was obtained by subtracting the $-\mathrm{COOH}$ group amount from the total acid amount. The electrochemical EDLC performance was investigated using a two-electrode cell with $\mathrm{KOH}$ aqueous solution $(6 \mathrm{M})$ as the electrolyte solution. Active carbon, carbon black, and polytetrafluoroethylene were mixed at a mass ratio of $8: 1: 1$; then, pellets ( $14 \mathrm{~mm}$ in diameter and $2 \mathrm{~mm}$ in thickness) were prepared and dried at $115^{\circ} \mathrm{C}$ for $24 \mathrm{~h}$ to obtain active carbon electrodes. Constant current charge-discharge testing (potential width: $0-1.0 \mathrm{~V}$, current density: $20-500 \mathrm{~mA} / \mathrm{g}$ ) was performed at room temperature. The specific capacity of the EDLC was calculated as follows: ${ }^{36}$

$$
C m=\frac{2 \times I \times \Delta t}{\Delta V \times m}
$$

where $\mathrm{Cm}$ is the specific gravimetric capacity $\left(\mathrm{F} \cdot \mathrm{g}^{-1}\right), I$ is the discharge current (A), $\Delta t$ is the discharge time (s), $\Delta V$ is the discharge voltage $(\mathrm{V})$, and $m$ is the mass $(\mathrm{g})$ of the active materials in a single electrode. Cyclic voltammetry was performed in the potential range of $-0.2-0.8 \mathrm{~V}$ with a scan rate $1 \mathrm{mV} / \mathrm{s}$. Electrochemical impedance spectroscopy was carried out over the frequency range of $0.001 \mathrm{~Hz}-10 \mathrm{kHz}$ at $5 \mathrm{mV}$ amplitude voltage in $6 \mathrm{M} \mathrm{KOH}$.

\section{Results and Discussion}

\subsection{Pore structure of active carbon samples}

Table 1 shows the pore structure of $1-\mu \mathrm{m}$-diameter active carbon particles treated at $700-800^{\circ} \mathrm{C}$ for different holding times to set $\mathrm{S}_{\mathrm{BET}}$ at ca. $1200 \mathrm{~m}^{2} / \mathrm{g}$, allowing elucidation of the factor controlling the specific capacity. ${ }^{34}$ For a holding time of $0.5 \mathrm{~h}$, the specific surface area $\left(\mathrm{S}_{\mathrm{BET}}\right)$ and total pore volume $\left(\mathrm{V}_{\text {tot }}\right)$ increased with increasing activation temperature. Xing et al. ${ }^{18}$ obtained lignite-derived active carbon by $\mathrm{KOH}$ activation at $600-800^{\circ} \mathrm{C}$ for $1 \mathrm{~h}$; their active carbons prepared at $700^{\circ} \mathrm{C}$ and $800^{\circ} \mathrm{C}$ had specific surface areas and total pore volumes of $2615 \mathrm{~m}^{2} / \mathrm{g}$ and $1.69 \mathrm{~cm}^{3} / \mathrm{g}$, and $3036 \mathrm{~m}^{2} / \mathrm{g}$ and $2.21 \mathrm{~cm}^{3} / \mathrm{g}$, respectively. They reported that higher activation temperature promoted pore generation and increased the specific surface area and total pore volume. Our results were similar in terms of temperature dependency. We found that increasing the holding time led to higher $\mathrm{V}_{\text {micro }}$ and lower $\mathrm{V}_{\text {meso }}$. Increasing the holding time promoted the following reactions and produced smaller pores: ${ }^{37}$

$$
\begin{aligned}
& \mathrm{C}_{\mathrm{n}}+\mathrm{K}_{2} \mathrm{CO}_{3}=\mathrm{C}_{\mathrm{n}-2}+2 \mathrm{~K}+3 \mathrm{CO} \\
& \mathrm{C}_{\mathrm{n}}+\mathrm{K}_{2} \mathrm{O}=\mathrm{C}_{\mathrm{n}-1}+2 \mathrm{~K}+\mathrm{CO}
\end{aligned}
$$

Table 1. Surface structure of active carbon treated at $700-800^{\circ} \mathrm{C}$ for different holding times.

\begin{tabular}{ccccccc}
\hline $\begin{array}{c}\text { Activation } \\
\text { temperature }\end{array}$ & $\begin{array}{c}\text { Holding } \\
\text { time }\end{array}$ & $\begin{array}{c}\mathrm{S}_{\mathrm{BET}} \\
{\left[\mathrm{cm}^{3} / \mathrm{g}\right]}\end{array}$ & $\begin{array}{c}\mathrm{V}_{\text {micro }} \\
{\left[\mathrm{cm}^{3} / \mathrm{g}\right]}\end{array}$ & $\begin{array}{c}\mathrm{V}_{\text {meso }} \\
{\left[\mathrm{cm}^{3} / \mathrm{g}\right]}\end{array}$ & $\begin{array}{c}\mathrm{V}_{\text {tot }} \\
{\left[\mathrm{cm}^{3} / \mathrm{g}\right]}\end{array}$ & $\begin{array}{c}\text { Mesopore } \\
\text { ratio [\%] }\end{array}$ \\
\hline \multirow{7}{7}{$700^{\circ} \mathrm{C}$} & $0 \mathrm{~h}$ & 1106 & 0.454 & 0.152 & 0.607 & 25.1 \\
& $0.25 \mathrm{~h}$ & 1292 & 0.521 & 0.188 & 0.709 & 26.5 \\
\cline { 2 - 7 } $750^{\circ} \mathrm{C}$ & $0.5 \mathrm{~h}$ & 1238 & 0.503 & 0.155 & 0.658 & 23.6 \\
\hline \multirow{7}{*}{$800^{\circ} \mathrm{C}$} & $0.25 \mathrm{~h}$ & 1162 & 0.456 & 0.383 & 0.840 & 45.7 \\
\hline & $0.5 \mathrm{~h}$ & 1421 & 0.593 & 0.268 & 0.862 & 31.1 \\
\hline & $0 \mathrm{~h}$ & 1291 & 0.511 & 0.429 & 0.939 & 45.6 \\
\hline & $0.5 \mathrm{~h}$ & 1492 & 0.590 & 0.359 & 0.949 & 37.8 \\
\hline & 1623 & 0.683 & 0.241 & 0.924 & 26.1 \\
\hline
\end{tabular}

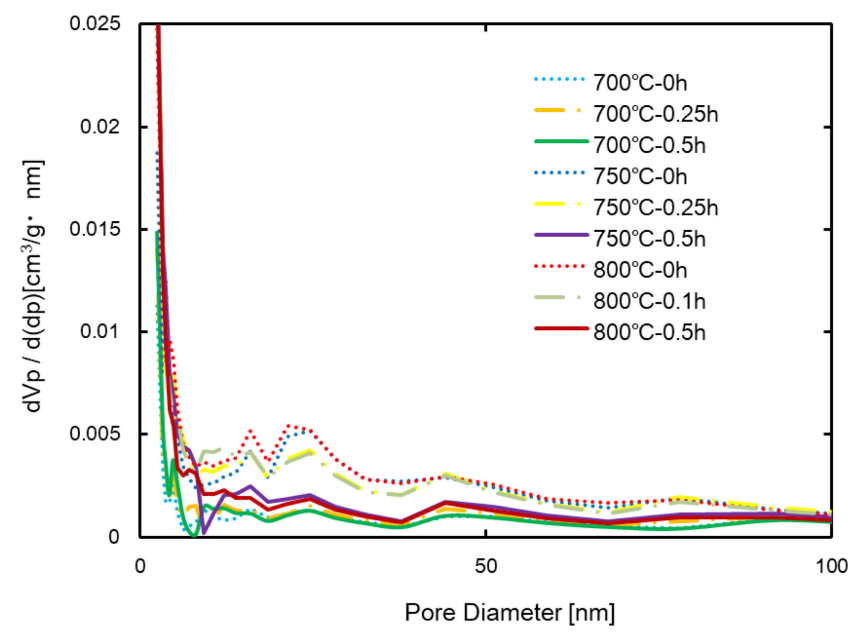

Figure 1. Pore size distributions of active carbon treated at 700$800^{\circ} \mathrm{C}$ for different holding times.

The three experimental conditions $\left(700^{\circ} \mathrm{C}-0.5 \mathrm{~h}, 750^{\circ} \mathrm{C}-0 \mathrm{~h}\right.$, and $800^{\circ} \mathrm{C}-0 \mathrm{~h}$ ) yielded active carbons with an $\mathrm{S}_{\mathrm{BET}}$ of $1200 \pm 100 \mathrm{~m}^{2} / \mathrm{g}$; these are indicated by the orange squares in Table 1. Active carbons produced at $750^{\circ} \mathrm{C}-0 \mathrm{~h}$ or $800^{\circ} \mathrm{C}-0 \mathrm{~h}$ had $2-3$-fold greater $\mathrm{V}_{\text {meso }}$ and 1.9-fold greater mesopore ratio than active carbon produced at $700^{\circ} \mathrm{C}-0.5 \mathrm{~h}$. Figure 1 shows the pore size distributions of these active carbons. Active carbons fabricated at $700^{\circ} \mathrm{C}$ had similar pore size distribution. Pore size distribution of active carbons fabricated at $750^{\circ} \mathrm{C}$ and $800^{\circ} \mathrm{C}$ depended on holding time.

\subsection{Surface chemical structure of active carbon samples}

Figure 2 shows the $\mathrm{C} 1 \mathrm{~s}$ X-ray photoelectron spectroscopy spectra of the samples, which provided details of the surface chemical structure. The $\mathrm{C} 1 \mathrm{~s}$ spectra were each deconvoluted into four peaks with binding energies of $284.6 \pm 0.5,286.4 \pm 0.4$, $287.6 \pm 0.5$, and $288.6 \pm 0.6 \mathrm{eV}$; these peaks were assigned to $\mathrm{C}-\mathrm{C}$, $\mathrm{C}-\mathrm{O}, \mathrm{C}=\mathrm{O}$, and $\mathrm{O}-\mathrm{C}=\mathrm{O}$ functional groups, respectively. Figure 3 shows surface functional group content ratio of samples. Figure 3 shows surface functional group content ratio of samples. The content ratio of $\mathrm{O}-\mathrm{C}=\mathrm{O}$ bond tends to decrease as the activation temperature increases. On the other hand, the content ratio of $\mathrm{C}=\mathrm{O}$ bond tends to increase with activation temperature. In $700^{\circ} \mathrm{C}-0.5 \mathrm{~h}$, $750^{\circ} \mathrm{C}-0 \mathrm{~h}$, and $800^{\circ} \mathrm{C}-0 \mathrm{~h}$, the content ratio of the $\mathrm{O}-\mathrm{C}=\mathrm{O}$ bond increased in the following order: $750^{\circ} \mathrm{C}-0 \mathrm{~h}(20.6 \%)<800^{\circ} \mathrm{C}-0 \mathrm{~h}$ $(21.2 \%)<700^{\circ} \mathrm{C}-0.5 \mathrm{~h}(29.6 \%)$ and the content ratio of the $\mathrm{C}=\mathrm{O}$ bond was larger for the $750^{\circ} \mathrm{C}-0 \mathrm{~h}(10.1 \%)$ or $800^{\circ} \mathrm{C}-0 \mathrm{~h}(10.3 \%)$ 

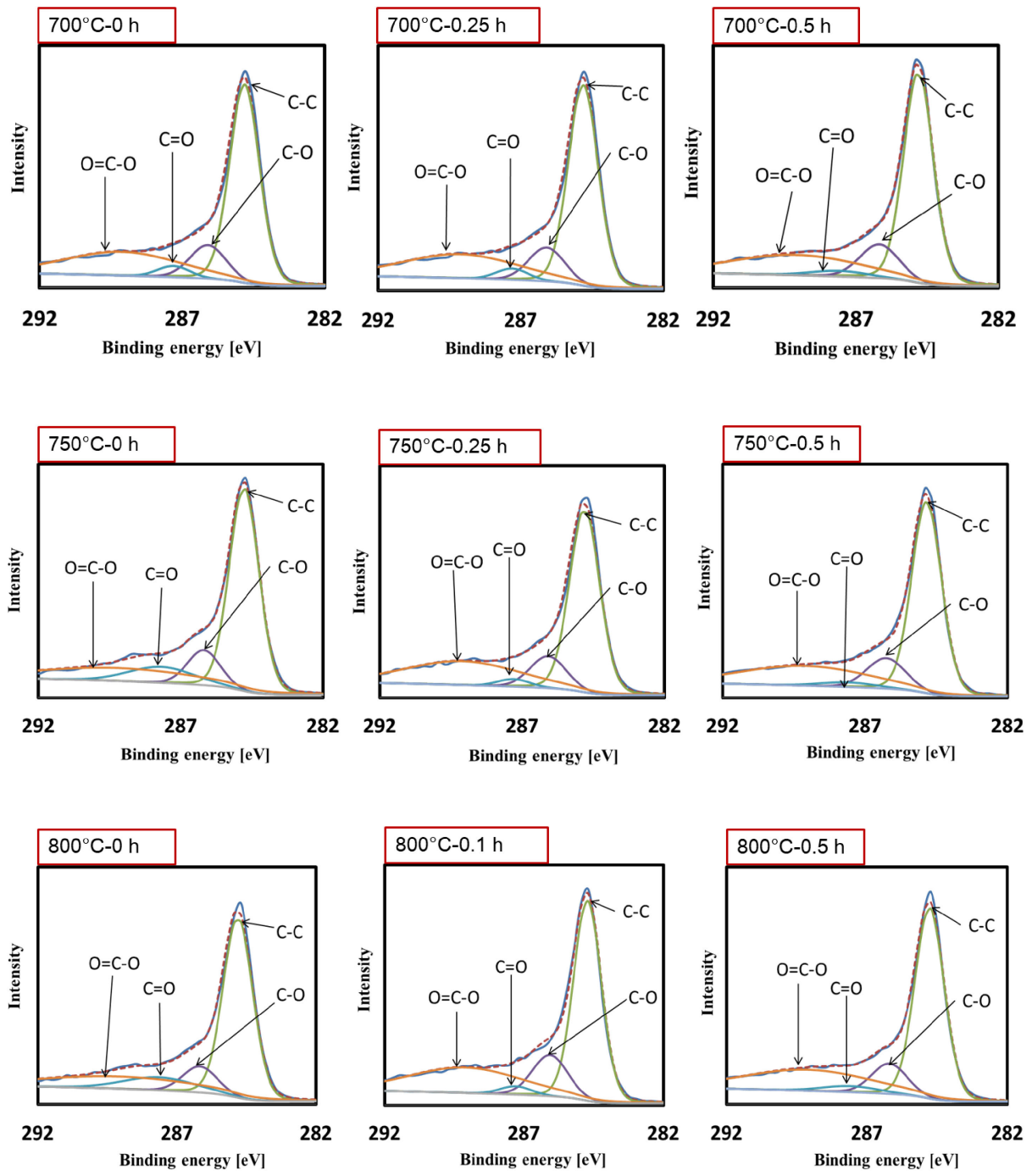

Figure 2. C1s X-ray photoelectron spectra of active carbon treated at $700-800^{\circ} \mathrm{C}$ for different holding times.

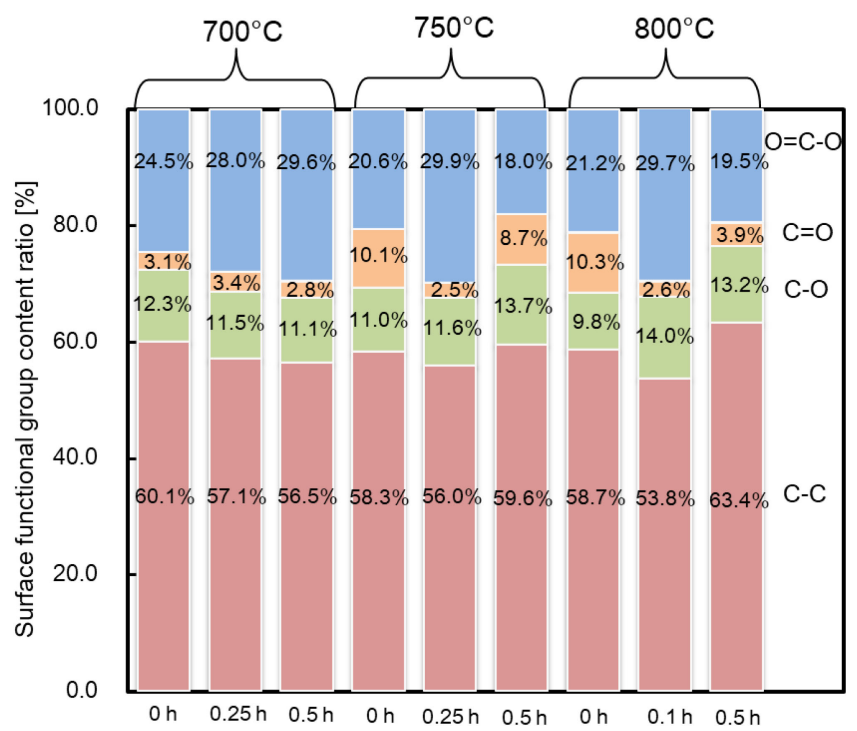

Figure 3. Surface functional group content ratio of active carbon treated at $700-800^{\circ} \mathrm{C}$ for different holding times.

active carbon than for the $700^{\circ} \mathrm{C}-0.5 \mathrm{~h}(2.8 \%)$ active carbons. Oxygen-containing functional groups can improve the wettability of electrode materials in aqueous electrolyte; they can also consid- erably enhance specific capacity through additional redox reactions. ${ }^{38,39}$ Such functional groups participate in the following redox reactions in the $\mathrm{KOH}$ aqueous electrolyte to produce additional pseudocapacity: ${ }^{40,41}$

$$
\begin{aligned}
& \mathrm{C}-\mathrm{OH} \Leftrightarrow \mathrm{C}=\mathrm{O}+\mathrm{H}^{+}+\mathrm{e}^{-} \\
& \mathrm{COOH} \Leftrightarrow \mathrm{COO}+\mathrm{H}^{+}+\mathrm{e}^{-} \\
& \mathrm{C}=\mathrm{O}+\mathrm{e}^{-} \Leftrightarrow-\mathrm{C}-\mathrm{O}^{-}
\end{aligned}
$$

A greater number of oxygen-containing functional groups can improve specific capacity; thus, interactions of these moieties via redox reactions may be important.

\subsection{Electrochemical performance of active carbon electrode materials in the EDLC}

Figure 4 shows the current density dependency of the chargedischarge performance of active carbon. The specific capacity was larger for active carbons fabricated at $700^{\circ} \mathrm{C}$ than for ones fabricated at $750^{\circ} \mathrm{C}$ and $800^{\circ} \mathrm{C}$. In $700^{\circ} \mathrm{C}-0.5 \mathrm{~h}, 750^{\circ} \mathrm{C}-0 \mathrm{~h}$, and $800^{\circ} \mathrm{C}-0 \mathrm{~h}$, the specific capacity increased in the following order: $700^{\circ} \mathrm{C}-0.5 \mathrm{~h}$ $(66 \mathrm{~F} / \mathrm{g})<800^{\circ} \mathrm{C}-0 \mathrm{~h} \quad(111 \mathrm{~F} / \mathrm{g})<750^{\circ} \mathrm{C}-0 \mathrm{~h} \quad(148 \mathrm{~F} / \mathrm{g})$. At low current densities, ions can sufficiently diffuse into surface micropores; at relatively high current densities, it is more difficult for ions to penetrate internal micropores, thereby reducing the specific capacity. ${ }^{20}$ Figure 5 shows $\mathrm{CV}$ curves at $1 \mathrm{mV} / \mathrm{s}$, suggesting all the sample has no pseudo capacity unlike conventional active carbon. Figure 6 shows the impedance measurement results for $700^{\circ} \mathrm{C}-0.5 \mathrm{~h}$, 


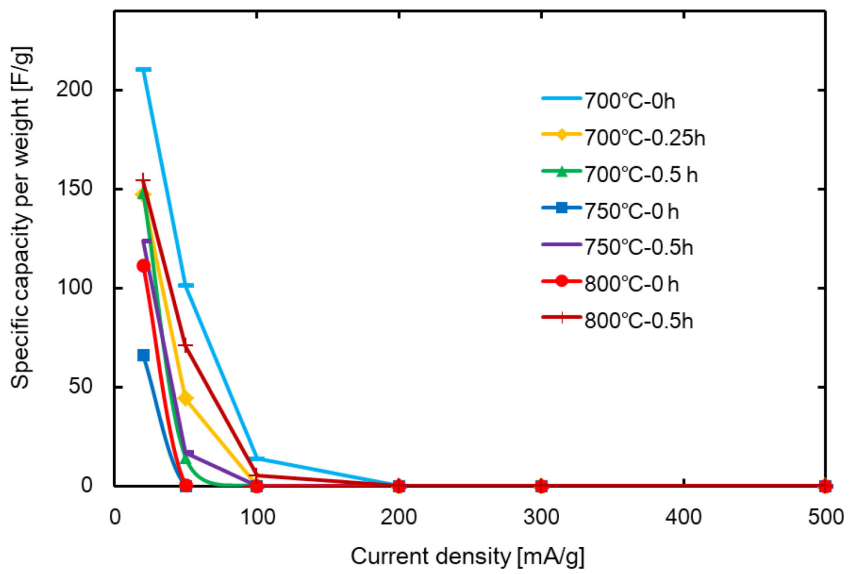

Figure 4. Current density dependency of the charge-discharge performance of active carbon.

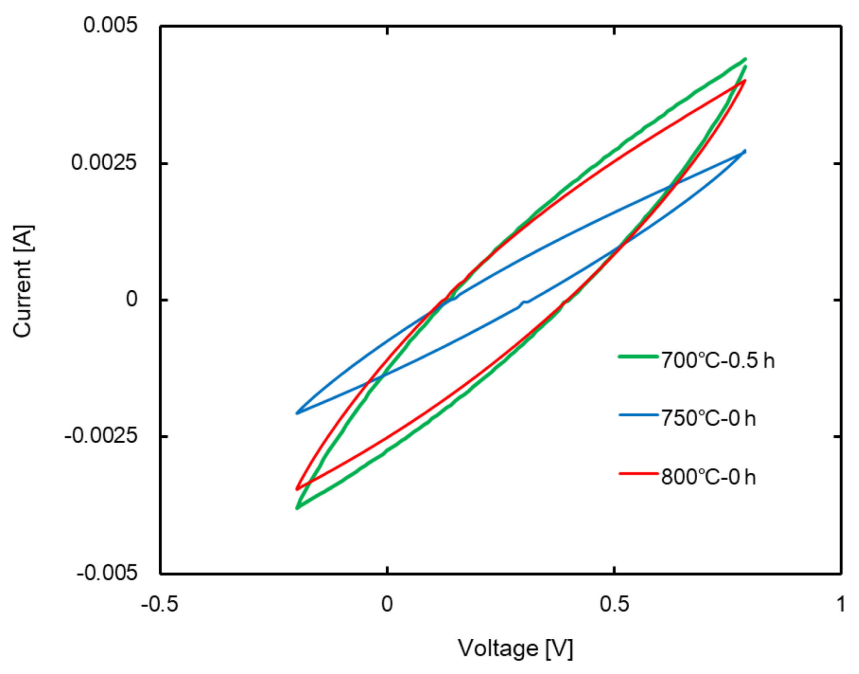

Figure 5. CV curves of active carbon with specific surface area of $1200 \pm 100 \mathrm{~m}^{2} / \mathrm{g}$.

$750^{\circ} \mathrm{C}-0 \mathrm{~h}$, and $800^{\circ} \mathrm{C}-0 \mathrm{~h}$. The Nyquist curve was linear in the lowfrequency region and appeared as a semicircular arc in the highfrequency region. ${ }^{42-45}$ The mid-frequency zone (i.e., Warburg impedance region) represents the resistance generated by diffusion of ions into the pores of active carbon. This resistance appeared as a straight line at an angle of $45^{\circ}$. The diameter of the semicircular arc corresponds to the dynamic resistance of charge transfer at the interface between the active carbon electrode and the electrolyte, or the intrinsic charge-transfer resistance of the porous electrode. ${ }^{46}$ The $750^{\circ} \mathrm{C}-0 \mathrm{~h}$ sample had a larger charge-transfer resistance, compared to the $700^{\circ} \mathrm{C}-0.5 \mathrm{~h}$ and $800^{\circ} \mathrm{C}-0 \mathrm{~h}$ samples. Kim et al. ${ }^{47}$ obtained resorcinol-formaldehyde active carbon by $\mathrm{CO}_{2}$ activation at $900^{\circ} \mathrm{C}$ for $2-6.5 \mathrm{~h}$. The active carbon prepared at a holding time of $2 \mathrm{~h}$ had a specific surface area of $2793 \mathrm{~m}^{2} / \mathrm{g}$, total pore volume of 1.30 $\mathrm{cm}^{3} / \mathrm{g}$, mesopore ratio of $7.7 \%$, and charge-transfer resistance of $54.0 \Omega$; the material produced at a holding time of $6.5 \mathrm{~h}$ had corresponding values of $3958 \mathrm{~m}^{2} / \mathrm{g}, 2.40 \mathrm{~cm}^{3} / \mathrm{g}, 20.8 \%$, and $14.0 \Omega$. The authors reported that high specific surface area and mesopore ratio contributed to low charge-transfer resistance. In our study, the $750^{\circ} \mathrm{C}-0 \mathrm{~h}$ and $800^{\circ} \mathrm{C}-0 \mathrm{~h}$ materials had similar specific surface area and pore size distribution, but markedly different electrochemical behavior. These results suggest that factors other than pore structure may greatly influence the electrochemical properties of active carbon.

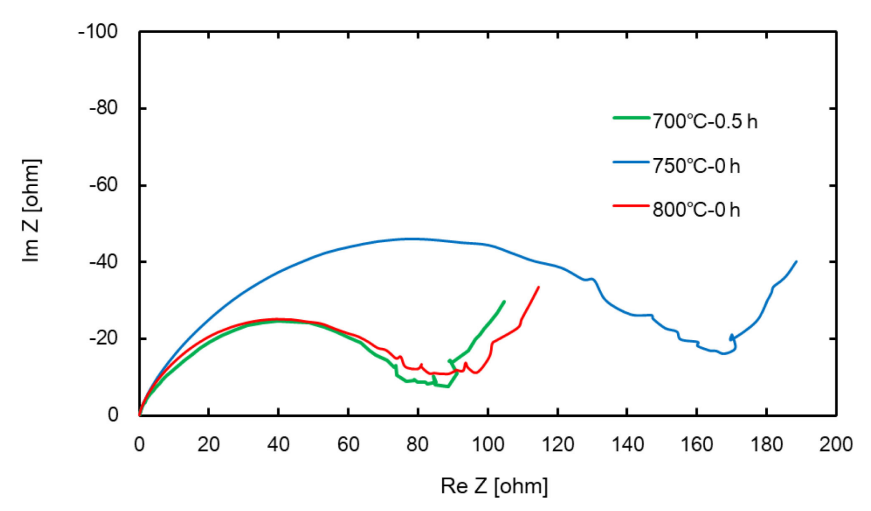

Figure 6. Impedance measurements of active carbon with specific surface area of $1200 \pm 100 \mathrm{~m}^{2} / \mathrm{g}$.

\subsection{Quantitative analysis of surface functional groups of active carbon samples}

The effect of acid-base back titration (Boehm method) on the surface functional groups was studied for $700^{\circ} \mathrm{C}-0.5 \mathrm{~h}, 750^{\circ} \mathrm{C}-0 \mathrm{~h}$, and $800^{\circ} \mathrm{C}-0 \mathrm{~h}$. The total acid amount increased in the following order: $750^{\circ} \mathrm{C}-0 \mathrm{~h} \quad(2.21 \mathrm{mmol} / \mathrm{g})<800^{\circ} \mathrm{C}-0 \mathrm{~h} \quad(2.45 \mathrm{mmol} / \mathrm{g})<$ $700^{\circ} \mathrm{C}-0.5 \mathrm{~h}(2.48 \mathrm{mmol} / \mathrm{g})$, which correlated with increasing capacity. Zhang et al. ${ }^{48}$ treated active carbon with nitric acid for up to $1 \mathrm{~h}$; the untreated and 1-h treated materials had a total acid amount and specific capacity of $0.90 \mathrm{mmol} / \mathrm{g}$ and $142 \mathrm{~F} / \mathrm{g}$, and $1.40 \mathrm{mmol} / \mathrm{g}$ and $229 \mathrm{~F} / \mathrm{g}$, respectively. The authors reported that oxygen-containing functional groups improved the wettability of electrode materials in aqueous electrolyte and facilitated redox reactions; thus, more oxygen-containing functional groups resulted in higher capacity. Our findings were similar to those of Zhang et al. Specifically, the lactone fraction increased in the following order: $700^{\circ} \mathrm{C}-0.5 \mathrm{~h}(9.7 \%)<800^{\circ} \mathrm{C}-0 \mathrm{~h}(10.6 \%)<750^{\circ} \mathrm{C}-0 \mathrm{~h}(24.5 \%)$; the trend in specific capacity was similar to that of the lactone fraction. Moreover, the carboxyl group fraction increased in the following order: $\quad 750^{\circ} \mathrm{C}-0 \mathrm{~h} \quad(18.1 \%)<800^{\circ} \mathrm{C}-0 \mathrm{~h} \quad(23.0 \%)<700^{\circ} \mathrm{C}-0.5 \mathrm{~h}$ $(31.4 \%)$. Thus, increasing the carboxyl group fraction could also improve the specific capacity. Cao et al. ${ }^{49}$ prepared active carbons by mixing mesophase pitch (MP) and biomass sawdust (BS) at different ratios $(\mathrm{MP} / \mathrm{BS}=10 / 0,7 / 3,5 / 5,3 / 7$, and $0 / 10)$, following $\mathrm{KOH}$ activation at $750^{\circ} \mathrm{C}$ for $1 \mathrm{~h}$. The $\mathrm{MP} / \mathrm{BS}=5 / 5$ material had a total acid amount of $2.74 \mathrm{mmol} / \mathrm{g}$ (carboxyl groups: $24.1 \%$; lactone: $23.7 \%$ ) and specific capacity of $324 \mathrm{~F} / \mathrm{g}$, while the $\mathrm{MP} / \mathrm{BS}=3 / 7$ material had corresponding values of $2.87 \mathrm{mmol} / \mathrm{g}$ (carboxyl groups: $20.6 \%$; lactone: $24.7 \%$ ) and $287 \mathrm{~F} / \mathrm{g}$. The MP/ $\mathrm{BS}=0 / 10$ material had a total acid amount of $4.98 \mathrm{mmol} / \mathrm{g}$ (carboxyl groups: $19.7 \%$; lactone: $37.3 \%$ ) and specific capacity of $291 \mathrm{~F} / \mathrm{g}$. These results indicate that oxygen-containing functional groups improve the wettability of electrode materials in aqueous electrolyte and can lead to redox reactions; furthermore, the carboxyl group is more influential than other oxygen-containing functional groups. However, the lactone fraction changed significantly, while the specific capacity did not; therefore, lactone exhibits reduced influence. Our research results agreed with those of Cao et al. Thus, the amount of surface carboxyl groups may have a greater influence on specific capacity, compared with pore structure.

\section{Conclusions}

We prepared active carbons by treating carburized furfural resin particles $\left(1 \mu \mathrm{m}\right.$ in diameter) with $\mathrm{KOH}$ for $0-0.5 \mathrm{~h}$ at $700-800^{\circ} \mathrm{C}$ in flowing nitrogen gas, then evaluated the pore structure and surface chemical structure. The $750^{\circ} \mathrm{C}-0 \mathrm{~h}$ and $800^{\circ} \mathrm{C}-0 \mathrm{~h}$ active carbons had 2.5 -fold greater mesopore volume and 1.9-fold greater mesopore 
ratio than the $700^{\circ} \mathrm{C}-0.5 \mathrm{~h}$ active carbon. The carboxyl group fraction increased in the following order: $750^{\circ} \mathrm{C}-0 \mathrm{~h}(18.1 \%)<$ $800^{\circ} \mathrm{C}-0 \mathrm{~h} \quad(23.0 \%)<700^{\circ} \mathrm{C}-0.5 \mathrm{~h} \quad(31.4 \%)$. The relationships among surface functional groups (determined by the Boehm method), pore size distribution, and EDLC capacity were investigated at constant $\mathrm{S}_{\mathrm{BET}}$. Our investigation showed that the amount of surface functional groups plays a crucial role in $6 \mathrm{M} \mathrm{KOH}$ electrolyte.

\section{Acknowledgments}

X-ray photoelectron spectroscopy was partly supported by the Nanotechnology Platform Program of the Ministry of Education, Culture, Sports, Science, and Technology (MEXT), Japan. This work was also supported by JSPS KAKENHI Grant Number K18k04709 and the Suzuki Foundation. The authors express their sincere appreciation to all involved.

\section{References}

1. J. R. Miller and P. Simon, Science, 321, 651 (2008).

2. C. Liu, F. Li, L. P. Ma, and H. M. Cheng, Adv. Mater, 22, E28 (2010).

3. M. V. Reddy, G. V. S. Rao, and B. V. R. Chowdari, Chem. Rev., 113, 5364 (2013).

4. A. Manthiram, Y. Fu, S. H. Chung, C. Zu, and Y. S. Su, Chem. Rev., 114, 11751 (2014).

5. N. Yabuuchi, K. Kubota, M. Dahbi, and S. Komaba, Chem. Rev., 114, 11636 (2014).

6. L. Zhang, X. Hu, Z. Wang, F. Sun, and D. G. Dorrell, Renewable Sustainable Energy Rev., 81, 1868 (2018).

7. T. N. Phan, M. K. Gong, R. Thangavel, Y. S. Lee, and C. H. Ko, J. Alloys Compd., 780, 90 (2019)

8. Z. S. Iro, C. Subramani, and S. S. Dash, Int. J. Electrochem. Sci., 11, 10628 (2016).

9. D. S. Jeong, J. M. Yun, and K. H. Kim, RSC Adv, 7, 44735 (2017).

10. G. Yu, X. Xie, L. Pan, Z. Bao, and Y. Cui, Nano Energy, 2, 213 (2013).

11. J. Yin, D. Zhang, J. Zhao, X. Wang, H. Zhu, and C. Wang, Electrochim. Acta, 136, 504 (2014).

12. X. T. Hong, K. S. Hui, Z. Zeng, K. N. Hui, L. Zhang, M. Mo, and M. Li, Electrochim. Acta, 130, 464 (2014).

13. X. Y. Zhao, S. S. Huang, J. P. Cao, X. Y. Wei, K. Magarisawa, and T. Takarada, Fuel Process. Technol., 125, 251 (2014).

14. S. Zhong, C. Zhan, and D. Cao, Carbon, 85, 51 (2015).

15. C. Zheng, X. Zhou, H. Cao, G. Wang, and Z. Liu, J. Power Sources, 258, 290 (2014).

16. G. P. Wang, L. Zhang, and J. Zhang, Chem. Soc. Rev., 41, 797 (2012).

17. J. A. Fernandez, S. Tennison, O. Kozynchenko, F. Rubiera, F. Stoeckli, and T. A. Centeno, Carbon, 47, 1598 (2009)

18. B. Xing, H. Guo, L. Chen, Z. Chen, C. Zhang, G. Huang, W. Xie, and J. Yu, Fuel
Process. Technol., 138, 734 (2015).

19. P. Simon and Y. Gogotsi, Nat. Mater., 7, 845 (2008).

20. Z. J. Qiao, M. M. Chen, C. Y. Wang, and Y. C. Yuan, Bioresour. Technol., 163, 386 (2014).

21. P. Hao, Z. Zhao, J. Tian, H. Li, Y. Sang, G. Yu, H. Cai, H. Liu, C. P. Wong, and A. Umar, Nanoscale, 6, 12120 (2014).

22. Q. Wang, J. Yan, Y. Wang, T. Wei, M. Zhang, X. Jing, and Z. Fan, Carbon, 67, 119 (2014).

23. S. Dutta, A. Bhaumik, and K. C. W. Wu, Energy Environ. Sci., 7, 3574 (2014).

24. C. Liu, Z. Yu, D. Neff, A. Zhamu, and B. Z. Jang, Nano Lett., 10, 4863 (2010).

25. C. Portet, P. L. Taberna, P. Simon, E. Flahaut, and C. L. Robert, Electrochim. Acta, 50, 4174 (2005)

26. J. Shen, A. Liu, Y. Tu, G. Foo, C. Yeo, M. B. C. Park, R. Jiang, and Y. Chen, Energy Environ. Sci., 4, 4220 (2011).

27. S. T. Senthilkumar, R. K. Selvan, J. S. Melo, and C. Sanjeeviraja, ACS Appl. Mater. Interfaces, 5, 10541 (2013).

28. L. Z. Fan, S. Qiao, W. Song, M. Wu, X. He, and X. Qu, Electrochim. Acta, 105, 299 (2013).

29. Z. B. Wen, Q. T. Qu, Q. Gao, X. W. Zheng, Z. H. Hu, Y. P. Wu, Y. F. Liu, and X. J. Wang, Electrochem. Commun., 11, 715 (2009).

30. R. S. Ray, B. Sarma, A. L. Jurovitzki, and M. Misra, Chem. Eng. J., 260, 671 (2015).

31. G. A. Tiruye, D. M. Torrero, T. Berthold, J. Palma, M. Antonietti, N. Fechler, and R. Marcilla, J. Mater. Chem. A, 5, 16263 (2017).

32. G. X. Wang, M. Zhang, H. F. Xu, L. Lu, Z. Xiao, and S. Liu, J. Energy Chem., 27, 1219 (2018)

33. R. R. Salunkhe, Y. V. Kaneti, J. Kim, J. H. Kim, and Y. Yamauchi, Acc. Chem. Res., 49, 2796 (2016).

34. K. Hokari, S. Suzuki, N. Okamoto, T. Saito, I. Ide, M. Nishikawa, and Y. Onishi, International Conference on Electronics Packaging (ICEP) Proceedings, P24, 441 (2019).

35. H. P. Boehm, Adv. Catal., 16, 179 (1966).

36. Q. Q. Zhou, J. Gao, C. Li, J. Chen, and G. Shi, J. Mater. Chem. A, 1, 9196 (2013).

37. Q. Wang, Q. Cao, X. Wang, B. Jing, H. Kuang, and L. Zhou, J. Power Sources, 225, 101 (2013).

38. M. Inagaki, H. Konno, and O. Tanaike, J. Power Sources, 195, 7880 (2010).

39. Z. B. Wen, Q. T. Qu, Q. Gao, X. W. Zheng, Z. H. Hub, Y. P. Wu, Y. F. Liu, and X. J. Wang, Electrochem. Commun., 11, 715 (2009).

40. H. F. Li, H. Xi, S. Zhu, Z. Wen, and R. Wang, Microporous Mesoporous Mater, 96, 357 (2006).

41. E. Frackowiak and F. Béguin, Carbon, 39, 937 (2001).

42. Y. X. Cui, J. Zhang, G. Li, Y. Sun, G. Zhang, and W. Zheng, Chem. Eng. J., 325, 424 (2017).

43. J. H. Shi, X. Li, G. He, L. Zhang, and M. Li, J. Mater. Chem. A, 3, 20619 (2015).

44. R. Ding, L. Qi, M. Jia, and H. Wang, Electrochim. Acta, 107, 494 (2013).

45. S. Zhang and N. Pan, Adv. Energy Mater, 5, 1401401 (2015).

46. N. L. Torad, R. R. Salunkhe, Y. Li, H. Hamoudi, M. Imura, Y. Sakka, C. C. Hu, and Y. Yamauchi, Chem. Eur. J., 20, 7895 (2014).

47. H. S. Kim, M. A. Abbas, M. S. Kang, H. Kyung, J. H. Bang, and W. C. Yoo, Electrochim. Acta, 304, 210 (2019).

48. M. Zhang, G. Wang, L. Lu, T. Wang, H. Xu, C. Yu, H. Li, and W. Tian, J. Saudi Chem. Soc., 22, 908 (2018)

49. S. Cao, J. Yang, J. Li, K. Shi, and X. Li, Diamond Relat. Mater., 96, 118 (2019). 